\title{
Psychological Factors Affecting Media Consumption Motivation of Bicultural Arab/Australian Consumers: The Mediating Role of Acculturation
}

\author{
Ahmad Khaldi ${ }^{1}$ \\ ${ }^{1}$ Australian College of Kuwait, Kuwait \\ Correspondence: Ahmad Khaldi, Australian College of Kuwait, West Mishref, Block 5, Al Aqsa Mosque Street, \\ Kuwait. E-mail: a.khaldi@ack.edu.kw
}

Received: May 15, 2014 Accepted: July 1, 2014 Online Published: September 28, 2014

doi:10.5539/ijms.v6n5p101ＵRL: http://dx.doi.org/10.5539/ijms.v6n5p101

\begin{abstract}
Societies today are far from being homogeneous. The growing trend toward multiculturalism needs to be recognized and understood so that better communication programs can be planned and implemented by marketers. This study examines the effect of personality openness and social adaptation motivation on the acculturation of bicultural Arab/Australian consumers and their motivation to use the host media. The findings of this research show positive effects among the variables of the study and confirm a model that was suggested to explain the inter-relationships among the researched variables. Several academic and practical implications are also discussed.
\end{abstract}

Keywords: acculturation, motivation, media consumption, bicultural consumption, personality openness, social motivation, cross cultural behavior, Arab Australian consumers

\section{Introduction}

Consumption choices cannot be understood without considering the cultural context in which they are made. The objective of this study is to investigate the effect of personality openness and social adaptation motivation on the acculturation of bicultural consumers and their motivation to use the host media. Solomon et al. (2006) defined culture as the totality of traditions, values, ethics, and rituals, as well as, the material objects and services; produced and valued by a group of people. Culture is a collective phenomenon that is learnt (Hofstede, 1991) and in order to understand how culture relates to consumption it is essential to understand how cultural behavior is formed and how it affects consumption habits. Within every culture, smaller subcultures can be found. Subcultures are groups of people with shared value systems due to common life experience and situation, such as nationality, religion, racial groups or geographic regions. Subcultures often make up important market segments, each with different consumption behaviors, and attracted to products and services in different ways (Armstrong \& Kotler, 2007). For example, Chattaraman and Lennon (2008) found that the strength of ethnic identification, among four subcultures in the USA, was a significant predictor of cultural apparel consumption, and also contributed to the construction of the emotions and meaning of consumption.

Australia is known to be a widely multicultural country with many ethnicities and mother tongues beside the English language. According to the Australian Bureau of Statistics in 2011 about 23.2 per cent of Australia's population speaks languages other than English at home. The third most commonly spoken non-English language Australia-wide is Arabic. Nevertheless, Arabic is the most spoken language, other than English, within the main state of New South Wales in Australia.

Communication behavior is a reflection of cultural dynamics, in which intangible aspects of culture are transmitted and consumed (Craig \& Douglas, 2006). This cultural behavior is based upon the values of what is acceptable and what is not (Albaum \& Duerr, 2008) including the choice of the source and purpose of communication. In the context of hosting country's media consumption by ethnic subcultures, it is essential to consider to which extent consumers identify with their country of origin, in contrast to their hosting country. One of the main factors that influence this process is the degree of consumer's acculturation which refers to the process of adaptation to another country; its culture and environment. This acculturation process will teach bicultural consumers the cultural ways and help them to navigate in the new environment of the culture of 
immigration (Solomon et al., 2006). According to the bi-dimensional theory, which is considered to be the most valid and useful conceptualization of acculturation (Ryder et al., 2000), this acculturation process will lead to new consumption patterns and adoption of products and behaviors from the hosting culture without losing the identification with the originating culture of bicultural consumers (Hwang \& He, 1999; Vijver \& Phalet, 2004). Indeed, host media consumption has been considered as an indication of bicultural consumers' acculturation level (Lam, 1980; Chaffee et al., 1990; Reece \& Palmgreen, 1996; Walker, 1999; Kim, 2001). Therefore, the first hypothesis of the current study posits that:

H1: there is a positive effect of the acculturation level of Arab/Australian consumers on their motivation to consume Australian media.

Several psychological factors can affect the level of acculturation of bicultural consumers. For example, Kunjara et al. (1988) have found that social adaptation motivation of Thailand students in USA has positively influenced their acculturation level. The same findings were further confirmed by Reece \& Palmgreen's study (1996) about the acculturation of Asian Indian graduates in an American University. Social adaptation is defined as the process of adjustment of humans to other individuals and community groups working together for a common purpose (Miller-Keane, 2003). Piontkowskia et al. (2000) considered the social adaptation variable as an efficient predictor of the acculturation attitudes of various groups within society. Neto (2002) found a strong link between the social adaptation of Portuguese migrants in France and their acculturation attitude. Plotka et al. (2008) have reported that expressed social adaptability of bicultural Russian/Latvian individuals was linked to their; positive attitude toward their social surrounding, sense of social protection, and sense of belonging to the new society.

Reflecting the above logic on bicultural Arab/Australian consumers, we can conclude that consumers' acculturation involves not only changes in identification and attitudes, but also changes in values and the acquisition of new social skills and norms, which is facilitated through the positive effect of social adaptation to the new environment. This positive effect of social adaptation will eventually lead Arab/Australians, through acculturation, to experience higher motivation to consume Australian media channels.

H2: There Is a Positive Effect Of Arab/Australian Consumers' Motivation of Social Adaptation on Their Level of Acculturation.

H3: The Positive Effect of Arab/Australian Consumers' Motivation of Social Adaptation on Their Motivation to Consume Australian Media is Mediated by Their Level of Acculturation.

Another factor that is confirmed to have a positive effect on acculturation is the personality openness trait. Openness is defined as a dimension of human personality that reflects individual differences in the ability and tendency to seek, detect, comprehend, utilize, and appreciate complex patterns of information, both sensory and abstract (DeYoung et al., 2007). Openness, as a psychological trait, distinguishes liberal and artistic individuals from conservative and traditional ones because it refers to being open to new experiences and ideas (Cambridge Personality Research, 2011).

McCrae \& Costa (1997) argue that personality openness should not be conceptualized as a trait that is acquired through education, or as a form of cognitive ability, but rather as a motivational need to increase the breadth, and depth of consciousness, in order to enlarge and examine new experiences of human beings. This opinion was later confirmed by Leininger (2002) who demonstrated that the un-acculturation of Vietnamese/Americans is due to their lower level of personality openness relative to the acculturated Vietnamese/Americans. Benet-Martínez \& Haritatos (2005) have gone a step further to explore the factors leading to higher bicultural integration of identities. They found that bicultural identity integration is directly affected by personality openness. That is the degree to which bicultural individuals perceives their two cultural identities as "compatible" versus "oppositional" depends on their level of openness as a psychological personality trait. In light of the above discussion, it is assumed that Arab/Australian consumers' level of personality openness has a positive effect of their acculturation, and eventually, on their motivation to consume Australian media.

\section{H4: There Is a Positive Effect Of Arab/Australian Consumers' Openness on Their Level of Acculturation.}

H5: The Positive Effect of Arab/Australian Consumers' Openness on Their Motivation to Consume Australian Media is Mediated by Their Level of Acculturation.

Finally, the reciprocal positive effect between personality openness and the motivation of social adaptation has been confirmed by many researchers (Winkelman, 1994; lopes et al., 2003; Ruiz, 2005; Ryan et al., 2011; Savickas \& Porfeli, 2012). Consumer's increased desire to adapt to new social surroundings will drive him/her to be more receptive to new experiences, behaviors, and ideas, which is an indication to increased openness. On the 
other hand, consumer's increased level of openness, will lead him/her to be more tolerant and positive in experiencing unfamiliar environment and accepting its new ways and behaviors. Therefore, the current study is adopting the following hypothesis.

H6: There is a Reciprocal Positive Effect between Arab/Australian Consumers' Motivation of Social Adaptation and Their Level of Personality Openness.

Building on the suggested hypotheses, this study is proposing the following model (Figure 1) that aims to identify the inter-effects among the researched variables.

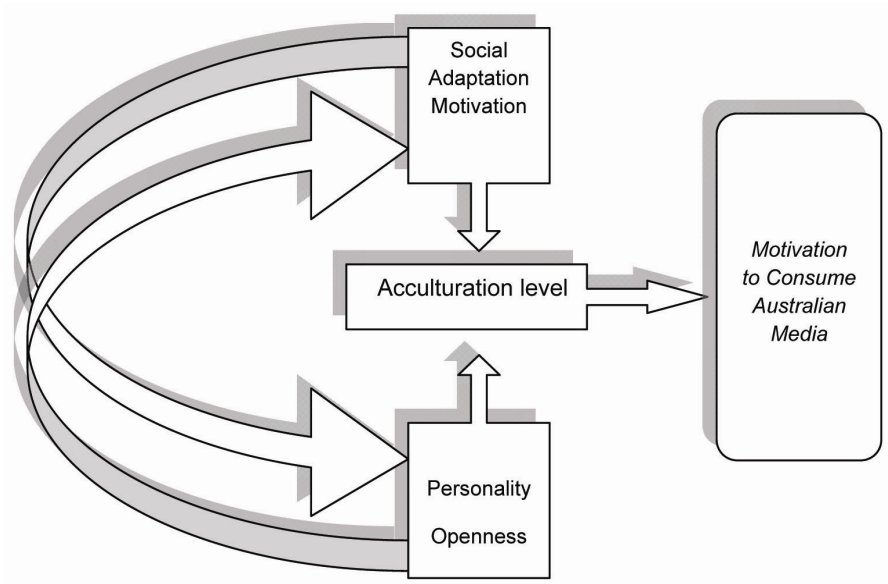

Figure 1. The proposed model of the study

\section{Measurement \& Methodology}

600 questionnaires were distributed to a convenient sample of Arab/Australian consumers residing in Sydney, Australia. The survey was conducted inside six shopping malls in areas where a large proportion of the local community is believed to be predominantly Arab/Australians. Before filling the questionnaires, respondents were individually asked to confirm their origins and only those who confirmed they were Arab/Australians were allowed to proceed. Out of the returned questionnaires, 274 ones were retained for analysis after discarding 27 incomplete cases. The first section of the questionnaire included items measuring the participants' gender, age, education level, social status and income level.

Previous researchers have identified diverse motivations for media consumption. Consumption motivations range from information seeking motives (Haridakis \& Hanson, 2009; Johnson \& Yang, 2010) to social connection motives (Bonds-Raacke \& Raacke, 2010; Chen, 2011), to entertainment motives (Shao, 2009; Lampe et al., 2010) and as an escape and distraction from everyday life (Dunne et al., 2010). Consumers' motivation to consume Australian media was measured using six motivational items corresponding to all media consumption motives mentioned in the previous literature. Respondents were asked to indicate their agreement with these six statements in the following order "I primarily use Australian media because I need to..." a) Obtain news and information, b) Remain connected to the Australian community, c) Educate myself about the language, behaviors, and social norms of Australian people, d) Entertain myself, e) Find grounds for conversation and social interaction and f) Kill time and take my mind off things. Responses were measured using a five-point "Likert" scale ranging from "strongly agree" to "strongly disagree".

Consumers acculturation level was measured using a modified version of the "Acculturation, Habits, and Interests Multicultural Scale AHIMSA" developed by Unger et al. (2002). Using a five point "Likert" scale ranging from "strongly agree" to "strongly disagree", respondents were asked to indicate their agreement with the following eight items of the Acculturation scale. 1. I feel comfortable being around Australian people. 2. The majority of my best friends are Australian. 3. The people I fit in with best are Australian. 4. Most of my favorite songs are Australian. 5. I love Australian TV shows. 6. I like to celebrate Australian holidays. 7. Most of the food I eat at home is from the Australian Kitchen. 8. The ways I think about, and do things, are similar to the Australian ways.

Consumers' personality openness was measured using a 13 items five-point differential scale developed by McCrae and Costa (1987) to calculate the openness level as one of the big five personality dimensions. 
Respondents were asked to rate themselves on each of the thirteen items. The scale included the following items: Conventional-original, Down to earth-imaginative, Uncreative-creative, Having narrow interests-Having broad interests, Simple-complex, Uncurious-curious, Unadventurous-daring, Prefer routine-prefer variety, Conforming-independent, Unanalytical-analytical, Conservative-liberal, Traditional-untraditional, Inartistic-artistic

Consumers' motivation of social adaptation was measured by using a scale developed by Hwang \& He (1999). Respondents were asked to indicate their agreement with the following four statements on a 5-point Likert scale ranging from "strongly agree" to "strongly disagree" a) I am interested in making Australian friends. b) I want to learn about Australian customs. c) I would like to participate in the Australian society. d) I hope to be part of the Australian mainstream.

\section{Data Analysis}

Of the 274 respondents 163 were males and 111 females. Most of the respondents aged between 35-44 years old (31\%) and held a high school or vocational diploma (42\%). Most respondents were married (53\%) and earned between 2000 to 2999, Australian Dollars a month (39\%). A reliability test was conducted for each of the investigated variables and all Cronbach Alpha coefficients were highly acceptable (Hair et al., 1986) as table 1 indicates.

Table 1. Cronbach Alpha coefficients of scales reliability tests

\begin{tabular}{lll}
\hline Scale Title & Number of Items & $\begin{array}{l}\text { Cronbach Alpha } \\
\text { coefficients }\end{array}$ \\
\hline Motivation to Consume Australian Media & 6 & 0.846 \\
Acculturation level & 8 & 0.821 \\
Social Adaptation Motivation & 4 & 0.817 \\
Personality Openness & 13 & 0.835 \\
\hline
\end{tabular}

The mean values for Arab/Australian consumers' motivation to consume Australian media are illustrated in Table 2 below.

Table 2. Mean values for Arab/Australian consumers' motivation to consume Australian media

\begin{tabular}{ll}
\hline I primarily use Australian media because I need to... & Mean \\
\hline Obtain news and information & 3.56 \\
Remain connected to the Australian community & 3.13 \\
Educate myself about the language, behaviors, and social norms of & 3.22 \\
Australian people & \\
Entertain myself & 2.99 \\
Find grounds for conversation and social interaction & 3.21 \\
Kill time and take my mind off things & 2.92 \\
\hline
\end{tabular}

Table 2 indicates that the strongest reason for Arab/Australian consumers to consume Australian media is to obtain news and information, whereas, "Self educate about the language, behaviors, and social norms of Australian people" and "Finding grounds for conversation and social interaction" are the two second most important reasons why Australian media is consumed. The least important reason however, is to "Kill time and take one's mind off things". Mean values for the aggregated variables of the study are shown in Table 3, which indicates above-moderate to high levels among respondents.

Table 3. Mean values for the aggregated variables of the study

\begin{tabular}{ll}
\hline Aggregated Variables Of The Study & Mean \\
\hline Motivation to Consume Australian Media & 3.16 \\
Acculturation level & 3.24 \\
Social Adaptation Motivation & 3.36 \\
Personality Openness & 3.54 \\
\hline
\end{tabular}


The first hypothesis of the study assumed that there is a positive effect of the acculturation level of Arab/Australian consumers on their motivation to consume Australian media. Regression analysis revealed a significant positive effect of the acculturation level of Arab/Australian consumers on their motivation to consume Australian media with positive coefficients $(b=0.437$ and $\beta=0.560$, Sig $=0.000)$ explaining about $31.4 \%\left(\mathrm{R}^{2}=0.314\right)$ of the variance in motivation to consume Australian media as shown in Table 4. Therefore, H1 is supported.

Table 4. Regression analysis of $\mathrm{H} 1$

\begin{tabular}{lllll}
\hline $\begin{array}{l}\text { Dependent Variable: } \\
\text { media consumption } \\
\text { motivation }\end{array}$ & $\begin{array}{l}\text { Un-standardized } \\
\text { Coefficients }\end{array}$ & $\begin{array}{l}\text { Standardized } \\
\text { Coefficients }\end{array}$ & Sig. & $\begin{array}{l}\text { Explained Variance } \\
\mathrm{R}^{2}\end{array}$ \\
\cline { 2 - 4 } & $\mathrm{B}$ & Beta & .000 & \\
\hline (Constant) & 1.739 & & .000 & \\
\hline Acculturation level & .437 & .560 & \\
\hline
\end{tabular}

The second hypothesis of the study posited that there is a positive effect of Arab/Australian consumers' motivation of social adaptation on their level of acculturation. Regression analysis revealed a significant positive effect of Arab/Australian consumers' motivation of social adaptation on their level of acculturation with positive coefficients $(b=0.675$ and $\beta=0.415$, Sig $=0.000)$ explaining about $17.2 \%\left(R^{2}=0.172\right)$ of the variance in acculturation as shown in Table 5. Therefore, $\mathrm{H} 2$ is supported.

Table 5. Regression analysis of $\mathrm{H} 2$

\begin{tabular}{lllll}
\hline $\begin{array}{l}\text { Dependent Variable: Acculturation } \\
\text { level }\end{array}$ & $\begin{array}{l}\text { Un-standardized } \\
\text { Coefficients }\end{array}$ & $\begin{array}{l}\text { Standardized } \\
\text { Coefficients }\end{array}$ & Sig. & $\begin{array}{l}\text { Explained Variance } \\
\mathrm{R}^{2}\end{array}$ \\
\cline { 2 - 4 } & $\mathrm{B}$ & Beta & \\
\hline (Constant) & 1.127 & & .006 \\
\hline motivation of social adaptation & .675 & .175 & .000 \\
\hline
\end{tabular}

Table 6. Regression analysis of $\mathrm{H} 3$

\begin{tabular}{|c|c|c|c|c|}
\hline \multirow[t]{2}{*}{$\begin{array}{l}\text { Dependent Variable: Acculturation } \\
\text { level }\end{array}$} & $\begin{array}{l}\text { Un-standardized } \\
\text { Coefficients }\end{array}$ & $\begin{array}{l}\text { Standardized } \\
\text { Coefficients }\end{array}$ & Sig. & $\begin{array}{l}\text { Explained Variance } \\
\mathrm{R}^{2}\end{array}$ \\
\hline & $\mathrm{B}$ & Beta & & \multirow{3}{*}{.172} \\
\hline (Constant) & 1.127 & & .006 & \\
\hline motivation of social adaptation & .675 & .415 & .000 & \\
\hline \multicolumn{5}{|l|}{ The First Equation } \\
\hline \multirow[t]{2}{*}{$\begin{array}{l}\text { Dependent Variable: motivation to } \\
\text { consume Australian media }\end{array}$} & $\begin{array}{l}\text { Un-standardized } \\
\text { Coefficients }\end{array}$ & $\begin{array}{l}\text { Standardized } \\
\text { Coefficients }\end{array}$ & Sig. & $\begin{array}{l}\text { Explained Variance } \\
\mathrm{R}^{2}\end{array}$ \\
\hline & $\mathrm{B}$ & Beta & & \multirow{3}{*}{.353} \\
\hline (Constant) & .779 & & .005 & \\
\hline motivation of social adaptation & .753 & .594 & .000 & \\
\hline \multicolumn{5}{|l|}{ The Second Equation } \\
\hline \multirow[t]{2}{*}{$\begin{array}{l}\text { Dependent Variable: motivation to } \\
\text { consume Australian media }\end{array}$} & $\begin{array}{l}\text { Un-standardized } \\
\text { Coefficients }\end{array}$ & $\begin{array}{l}\text { Standardized } \\
\text { Coefficients }\end{array}$ & Sig. & $\begin{array}{l}\text { Explained Variance } \\
\mathrm{R}^{2}\end{array}$ \\
\hline & $\mathrm{B}$ & Beta & & \multirow{3}{*}{.314} \\
\hline (Constant) & 1.739 & & .000 & \\
\hline Acculturation level & .437 & .560 & .000 & \\
\hline \multicolumn{5}{|l|}{ The Third Equation } \\
\hline \multirow[t]{2}{*}{$\begin{array}{l}\text { Dependent Variable: motivation to } \\
\text { consume Australian media }\end{array}$} & $\begin{array}{l}\text { Un-standardized } \\
\text { Coefficients }\end{array}$ & $\begin{array}{l}\text { Standardized } \\
\text { Coefficients }\end{array}$ & Sig. & $\begin{array}{l}\text { Explained Variance } \\
\mathrm{R}^{2}\end{array}$ \\
\hline & $\mathrm{B}$ & Beta & & \multirow{4}{*}{.472} \\
\hline (Constant) & .447 & & .084 & \\
\hline Acculturation level & .554 & .437 & .000 & \\
\hline motivation of social adaptation & .117 & .102 & .094 & \\
\hline The Fourth Equation & & & & \\
\hline
\end{tabular}


The third hypothesis stated that the positive effect of Arab/Australian consumers' motivation of social adaptation on their motivation to consume Australian media is mediated by their level of acculturation. The mediating effect, of the Arab/Australian consumers' acculturation, is examined through the procedures that were recommended by Baron and Kenny (1986). Simple and multiple regression analysis indicate that the four equations for a successful test of mediation, according to Baron and Kenny (1986), are fulfilled as shown in table 6. In the first equation, the motivation of social adaptation is significantly influencing $(\beta=.415 \mathrm{Sig}=.000)$ the level of acculturation. In the second equation, the motivation of social adaptation is significantly influencing $(\beta=.594$ $\mathrm{Sig}=.000)$ the motivation to consume Australian media. In the third equation, the level of acculturation is significantly influencing $(\beta=.560 \mathrm{Sig}=.000)$ the motivation to consume Australian media. In the fourth equation, the effect of the motivation of social adaptation reduces in size and becomes non-significant $(\beta=.102$ $\mathrm{Sig}=.094)$ when the level of acculturation is introduced. Therefore, H3 is supported.

The fourth hypothesis of the study posited that there is a positive effect of Arab/Australian consumers' openness on their level of acculturation. Regression analysis revealed a significant positive effect of Arab/Australian consumers' openness on their level of acculturation with positive coefficients $(b=0.767$ and $\beta=0.661$, Sig $=$ $0.000)$ explaining about $43.6 \%\left(\mathrm{R}^{2}=0.436\right)$ of the variance in acculturation as shown in Table 7 . Therefore, $\mathrm{H} 4$ is supported.

Table 7. Regression analysis of $\mathrm{H} 4$

\begin{tabular}{lllll}
\hline $\begin{array}{l}\text { Dependent Variable: Acculturation } \\
\text { level }\end{array}$ & $\begin{array}{l}\text { Un-standardized } \\
\text { Coefficients }\end{array}$ & $\begin{array}{l}\text { Standardized } \\
\text { Coefficients }\end{array}$ & Sig. & $\begin{array}{l}\text { Explained Variance } \\
\mathrm{R}^{2}\end{array}$ \\
\cline { 2 - 4 } & $\mathrm{B}$ & Beta & .001 \\
\hline (Constant) & .852 & & .000 \\
\hline
\end{tabular}

Table 8. Regression analysis of H5

\begin{tabular}{|c|c|c|c|c|}
\hline \multirow[t]{2}{*}{$\begin{array}{l}\text { Dependent Variable: Acculturation } \\
\text { level }\end{array}$} & $\begin{array}{l}\text { Un-standardized } \\
\text { Coefficients }\end{array}$ & $\begin{array}{l}\text { Standardized } \\
\text { Coefficients }\end{array}$ & Sig. & $\begin{array}{l}\text { Explained Variance } \\
\mathrm{R}^{2}\end{array}$ \\
\hline & $\mathrm{B}$ & Beta & & \multirow{3}{*}{.436} \\
\hline (Constant) & .852 & & .001 & \\
\hline Personality Openness & .767 & .661 & .000 & \\
\hline \multicolumn{5}{|l|}{ The First Equation } \\
\hline \multirow[t]{2}{*}{$\begin{array}{l}\text { Dependent Variable: motivation to } \\
\text { consume Australian media }\end{array}$} & $\begin{array}{l}\text { Un-standardized } \\
\text { Coefficients } \\
\end{array}$ & $\begin{array}{l}\text { Standardized } \\
\text { Coefficients } \\
\end{array}$ & Sig. & $\begin{array}{l}\text { Explained Variance } \\
\mathrm{R}^{2}\end{array}$ \\
\hline & $\mathrm{B}$ & Beta & & \multirow{3}{*}{.374} \\
\hline (Constant) & 1.425 & & .000 & \\
\hline Personality Openness & .553 & .611 & .000 & \\
\hline \multicolumn{5}{|l|}{ The Second Equation } \\
\hline \multirow[t]{2}{*}{$\begin{array}{l}\text { Dependent Variable: motivation to } \\
\text { consume Australian media }\end{array}$} & $\begin{array}{l}\text { Un-standardized } \\
\text { Coefficients }\end{array}$ & $\begin{array}{l}\text { Standardized } \\
\text { Coefficients }\end{array}$ & Sig. & $\begin{array}{l}\text { Explained Variance } \\
\mathrm{R}^{2}\end{array}$ \\
\hline & $\mathrm{B}$ & Beta & & \multirow{3}{*}{.314} \\
\hline (Constant) & 1.739 & & .000 & \\
\hline Acculturation level & .437 & .560 & .000 & \\
\hline \multicolumn{5}{|l|}{ The Third Equation } \\
\hline \multirow[t]{2}{*}{$\begin{array}{l}\text { Dependent Variable: motivation to } \\
\text { consume Australian media }\end{array}$} & $\begin{array}{l}\text { Un-standardized } \\
\text { Coefficients }\end{array}$ & $\begin{array}{l}\text { Standardized } \\
\text { Coefficients }\end{array}$ & Sig. & $\begin{array}{l}\text { Explained Variance } \\
\mathrm{R}^{2}\end{array}$ \\
\hline & $\mathrm{B}$ & Beta & & \multirow{4}{*}{.417} \\
\hline (Constant) & 1.241 & & .000 & \\
\hline Acculturation level & .216 & .278 & .001 & \\
\hline Personality Openness & .152 & .109 & .068 & \\
\hline The Fourth Equation & & & & \\
\hline
\end{tabular}

The fifth hypothesis stated that the positive effect of Arab/Australian consumers' openness on their motivation to consume Australian media is mediated by their level of acculturation. The mediating effect, of the Arab/Australian consumers' acculturation, is also examined through the procedures that were recommended by Baron and Kenny (1986). Simple and multiple regression analysis indicate that the four equations for a 
successful test of mediation are fulfilled as shown in table 8. In the first equation, personality openness is significantly influencing $(\beta=.661 \mathrm{Sig}=.000)$ the level of acculturation. In the second equation, personality openness is significantly influencing $(\beta=.611 \mathrm{Sig}=.000)$ the motivation to consume Australian media. In the third equation, the level of acculturation is significantly influencing $(\beta=.560 \mathrm{Sig}=.000)$ the motivation to consume Australian media. In the fourth equation, the effect of personality openness reduces in size and becomes non-significant $(\beta=.109 \mathrm{Sig}=.068)$ when the level of acculturation is introduced. Therefore, H5 is supported.

The sixth hypothesis of the study posited that there is a reciprocal positive effect between Arab/Australian consumers' motivation of social adaptation and their personality openness. Regression analysis revealed a significant positive effect of Arab/Australian consumers' motivation of social adaptation on their personality openness with positive coefficients $(b=0.726$ and $\beta=0.518$, Sig $=0.000)$ explaining about $26.9 \%\left(R^{2}=0.269\right)$ of the variance in personality openness as shown in Table 9.

Table 9. Regression analysis of H6 part 1

\begin{tabular}{lllll}
\hline $\begin{array}{l}\text { Dependent Variable: Personality } \\
\text { Openness }\end{array}$ & $\begin{array}{l}\text { Un-standardized } \\
\text { Coefficients }\end{array}$ & $\begin{array}{l}\text { Standardized } \\
\text { Coefficients }\end{array}$ & Sig. & $\begin{array}{l}\text { Explained Variance } \\
\mathrm{R}^{2}\end{array}$ \\
\cline { 2 - 4 } & $\mathrm{B}$ & Beta & \\
\hline (Constant) & .847 & & .010 \\
\hline motivation of social adaptation & .726 & .518 & .000 \\
\hline
\end{tabular}

Regression analysis also revealed a significant positive effect of Arab/Australian consumers' openness on their motivation of social adaptation with positive coefficients $(b=0.370$ and $\beta=0.518$, Sig $=0.000)$ as shown in Table 10. Therefore, H6 is supported.

Table 10. Regression analysis of $\mathrm{H6}$ part 2

\begin{tabular}{|c|c|c|c|c|}
\hline \multirow[t]{2}{*}{$\begin{array}{l}\text { Dependent Variable: motivation of } \\
\text { social adaptation }\end{array}$} & $\begin{array}{l}\text { Un-standardized } \\
\text { Coefficients }\end{array}$ & $\begin{array}{l}\text { Standardized } \\
\text { Coefficients }\end{array}$ & Sig. & $\begin{array}{l}\text { Explained Variance } \\
\mathrm{R}^{2}\end{array}$ \\
\hline & $\mathrm{B}$ & Beta & & \multirow{3}{*}{.269} \\
\hline (Constant) & 2.003 & & .000 & \\
\hline Personality Openness & .370 & .518 & .000 & \\
\hline
\end{tabular}

The cross-tabulation of respondents' gender, social status and income level with all variables of the study produced non-significant Cramer's V and contingency coefficient values which indicate no association with the investigated variables. However, respondents' age and education level produced some significant Cramer's V and contingency coefficient values as Table 11 shows.

Table 11. Respondents' age and education level associations with the variables of the study

\begin{tabular}{lllll}
\hline Age & Media Usage & Acculturation & Social Adaptation & openness \\
\hline V. & .226 & 14.7 & .160 & .049 \\
C.C. & .195 & 14.6 & .158 & .046 \\
Sig. & .032 & .042 & .024 & .708 \\
\hline Education & Media Usage & Acculturation & Social Adaptation & openness \\
\hline V. & .200 & .189 & .102 & .153 \\
C.C. & .196 & .186 & .101 & .151 \\
Sig. & .021 & .006 & .222 & .034 \\
\hline
\end{tabular}

Table 11 indicates that there is an association between respondents' age and their motivation for social adaptation, acculturation level, and their motivation to use Australian media. Respondents' education level is also associated with their personality openness, acculturation level, and their motivation to use Australian media.

The final objective of this study was to introduce a model that explains the inter-relationships between the variables of the study. Regression and correlation analysis have already proved a number of positive direct relationships amongst these variables. In order to confirm the proposed model of the study, Structural Equation 
Modeling (SEM) is used to assess model fitness to actual data through providing the goodness of fit indexes (Byrne, 1998). The final model that was produced by SEM, which further confirmed regression analysis results, is shown in Figure 2. Model fit indexes which were produced also showed an acceptable fit of the final model, as Table 12 indicates.

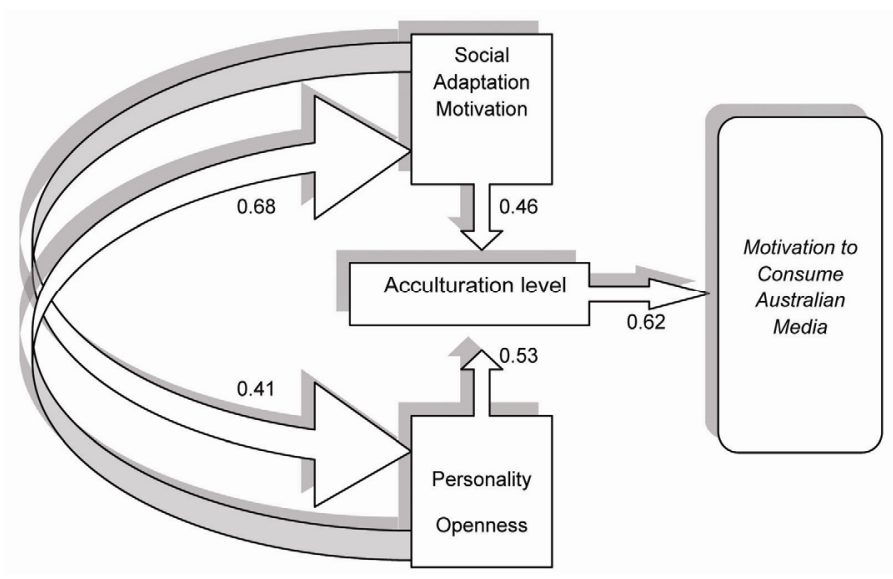

Figure 2. The final model of the study

Table 12. Fitness indexes for the final model of the study

\begin{tabular}{lll}
\hline Fit Indexes & Acceptable Levels & Calculated Indexes \\
\hline Absolute & & \\
Chi-square & Smaller $X^{2}$ & 12.274 \\
Sig. value & $\mathrm{P}>0.05$ & $\mathrm{P}=0.65$ \\
GFI & $>0.90$ & 0.948 \\
RMSR & & 0.062 \\
SRMR & $<0.08$ acceptable & 0.058 \\
RMSEA & & 0.054 \\
\hline Incremental & & \\
AGFI & & 0.941 \\
NFI & & 0.969 \\
NNFI & $>0.90$ & 0.947 \\
IFI & & 0.955 \\
CFI & & 0.952 \\
\hline
\end{tabular}

\section{Results Discussion}

It appears that the acculturating of bicultural Arab/Australian consumers is closely dependent on their motivation to adopt the Australian social norms and lifestyle as well as their openness to accept new ideas and cultures. The process of acculturation will lead bicultural consumers to be motivated to more consumption of the host media as a source of valuable information and as a form of self education. In doing so, bicultural consumers will be able to adapt to the new environment and become more assimilated with the new society. These findings were consistent with Hwang and He's study (1999) which reported that immigrants used host media for social learning that is required to be settled into the new society. Therefore, advertisers have to design their message, appeal, and execution style to fit the informative, educational, and entertainment needs of the bicultural customer if they want to reach this segment of the market.

Among the demographic factors measured in this study, only age and education were found to correlate significantly with the variables of the study which is consistent with Delener and Neelankavil (1990) findings. Younger bicultural consumers can adapt more easily with the new society and have higher acculturation level and motivation to use Australian media than older consumers. Similarly, the higher the respondents' level of education the more receptive they become to experience the new lifestyle which will facilitate their acculturation process and motivate them more to use Australian media. 
Compared to demographic variables, psychological factors appeared to be more influential on respondents' media consumption motivation. Hence, this study draws the attention to the importance of social adaptation and personality openness as influential psychological factors in consumer acculturation. The stronger these factors are the higher the acculturation levels and the motivation to use Australian media among bicultural consumers. The findings of this study indicate that psychological variables, not demographic backgrounds, are the primary factors which influence bicultural consumers' host media consumption motivation. In other words, psychological factors have more evident impact than demographic factors on media usage. This result should lead marketers to segment ethic consumers according to their psychological characteristics rather than demographics as most marketers tend to do.

Future studies can compare different ethnic groups of consumers, investigating their media consumption patterns and the effectiveness of various advertising appeals and host product consumption. Finally, researchers can investigate the effect of other psychological variables like self image and reference group influence to further enrich our understanding of bicultural consumption.

\section{References}

Albaum, G., \& Duerr, E. (2008). International marketing and export management (6th Ed.). Harlow, England: Financial Times/Prentice Hall.

Armstrong, G., \& Kotler, P. (2007). Marketing: An introduction (8th Ed.). Upper Saddle River, New Jersey: Pearson Prentice Hall.

Baron, R. M., \& Kenny D. A. (1986). The Moderator-Mediator Variable Distinction in Social Psychological Research: Conceptual, Strategic and Statistical Considerations. Journal of Personality and Social Psychology, 51(6), 1173-1182. http://dx.doi.org/10.1037/0022-3514.51.6.1173

Benet-Martínez, V., \& Haritatos, J. (2005). Bicultural Identity Integration (BII): Components and Psychosocial $\begin{array}{llll}\text { Antecedents. } & \text { Journal }\end{array}$ http://dx.doi.org/10.1111/j.1467-6494.2005.00337.x

Bonds-Raacke, J., \& Raacke, J. (2010). MySpace and Facebook: Identifying dimensions of uses and gratifications for friend networking sites. Individual Differences Research, 8(1), 27-33.

Byrne, B. M. (1998). Structural equation modeling with LISREL, PRELIS, and SIMPLIS: Basic concepts, applications and programming. Mahwah, NJ: Lawrence Erlbaum.

Cambridge Personality Research. (2011). Personality-trait: openness. Retrieved from $\mathrm{http}: / /$ cambridgepersonality.com/index.php/science-menu22/77-trait-description-openness

Chaffee, S. H., Nass, C., \& Yang, S. (1990). The bridging role of television in immigrant political socialization. Human Communication Research, 17(2), 266-288. http://dx.doi.org/10.1111/j.1468-2958.1990.tb00233.x

Chattaraman, V., \& Lennon, S. J. (2008). Ethnic identity, consumption of cultural apparel, and self-perceptions of ethnic consumers. Journal of Fashion Marketing and Management, 12(4), 518-531. http://dx.doi.org/10.1108/13612020810906164

Chen, G. M. (2011). Tweet this: A uses and gratifications perspective on how active Twitter use gratifies a need to connect with others. Computers in Human Behavior, 27(2), 755-762. http://dx.doi.org/10.1016/j.chb.2010.10.023

Craig, C. S., \& Douglas, S. P. (2006). Beyond national Culture: implications of cultural dynamics for consumer research. International Marketing Review, 23(3), 322-342. http://dx.doi.org/10.1108/02651330610670479

Delener, N., \& Neelankavil, J. P. (1990). Informational sources and media usage: A comparison between Asian and Hispanic subcultures. Journal of Advertising Research, 30(June/July), 45-52.

DeYoung, C. G., Quilty, L. C., \& Peterson, J. B. (2007). Between facets and domains: 10 aspects of the Big Five. Journal of Personality and Social Psychology, 93(5), 880-896. http://dx.doi.org/10.1037/0022-3514.93.5.880

Dunne, A., Lawlor, M. A., \& Rowley, J. (2010). Young people's use of online social networking sites: A uses and gratifications perspective. Journal of Research in Interactive Marketing, 4(1), 46-58. http://dx.doi.org/10.1108/17505931011033551

Hair, J. F., Anderson, R. E., \& Tatham, R. L. (1986). Multivariate Data Analysis (2nd Ed.). Indianapolis: Macmillan Publishing Co. 
Haridakis, P., \& Hanson, G. (2009). Social interaction and co-viewing with YouTube: Blending mass communication reception and social connection. Journal of Broadcasting and Electronic Media, 53(1), 317-335. http://dx.doi.org/10.1080/08838150902908270

Hofstede, G. (1991). Cultures and Organizations: Software of the Mind. London: McGraw-Hill.

Hwang, B. H., \& He, Z. (1999). Media uses and acculturation among Chinese immigrants in the U.S.A. International Communication Gazette, 61(1), 5-22. http://dx.doi.org/10.1177/0016549299061001001

Johnson, P. R., \& Yang, S. U. (2010). Uses and gratifications of Twitter: An examination of user motives and satisfaction of Twitter use. Unpublished manuscript, S. I. Newhouse School of Public Communications, Syracuse University, Syracuse, NY.

Kim, Y. (2001). Becoming intercultural. Newbury Park, CA: Sage.

Kunjara, K., Hill, B., \& Lakey, P. (1988). Communication patterns of Thai students in the process of acculturation. Paper Presented at the Annual Convention of the International Communication Association, New Orleans.

Lam, L. (1980). The role of ethnic media for immigrants: A case study of Chinese immigrants and their media in Toronto. Canadian Ethnic Studies, 12(1), 74-92.

Lampe, C., Wash, R., Velasquez, A., \& Ozkaya, E. (2010). Motivations to participate in online communities. Proceedings of the ACM Conference on Human Factors in Computing Systems (CHI). Retrieved from http://rickwash.org/papers/pap1604_lampe.pdf

Leininger, A. (2002). The Five-Factor Model of Personality Across Cultures: Vietnamese-American Personality and Acculturation. International and Cultural Psychology Series, 197-225.

Lopes, P., Salovey, P., \& Straus, R. (2003). Emotional intelligence, personality, and the perceived quality of social relationships. Personality and Individual Differences, 35(3), 641-658. http://dx.doi.org/10.1016/S0191-8869(02)00242-8

McCrae, R., \& Costa Jr., T. (1997). Conceptions and correlates of openness to experience. In R. Hogan, A. Johnson, \& R. Briggs (Eds.), Handbook of personality psychology. San Diego, CA: Academic Press. http://dx.doi.org/10.1016/B978-012134645-4/50032-9

McCrae, R., \& Costa, P. (1987). Validation of the Five-Factor Model of Personality Across Instruments and Observers. Journal of Personality and Social Psychology, 52(1), 81-90. $\mathrm{http}: / / \mathrm{dx}$. doi.org/10.1037/0022-3514.52.1.81

Miller-Keane, S. (2003). Encyclopedia and Dictionary of Medicine, Nursing, and Allied Health (7th ed.). Elsevier Inc.

Neto, F. (2002). Social Adaptation Difficulties of Adolescents with Immigrant Backgrounds. Social Behavior and Personality: An International Journal, 30(4), 335-345. http://dx.doi.org/10.2224/sbp.2002.30.4.335

Piontkowskia, U., Floracka, A., Hoelkera, P., \& Obdrzálekb, P. (2000). Predicting acculturation attitudes of dominant and non-dominant groups. International Journal of Intercultural Relations, 24(1), 1-26. http://dx.doi.org/10.1016/S0147-1767(99)00020-6

Plotka, I. et al. (2008). Ethnic Identity and Social Adaptation in the different cultural spheres for the different ethnic groups. In A. Ross \& P. Cunningham (Eds.), Reflecting on Identities: Research, Practice and Innovation (pp. 145-158). London: CiCe.

Reece, D., \& Palmgreen, P. (1996). Coming to America: The influence of cultural variables on media use among Indian sojourners in the U.S. Paper presented at the annual meeting of the International Communication Association, Chicago.

Ruiz, V. M. (2005). The Five-Factor Model Of Personality, Subjective Well-Being, and Social Adaptation: Generalizability to the Spanish Context. Psychological Reports, 96(3), 863-866. http://dx.doi.org/10.2466/pr0.96.3.863-866

Ryan, S., Magro, M., \& Sharp, J. (2011). Exploring Educational and Cultural Adaptation through Social Networking Sites. Journal of Information Technology Education, 10(1), 1-16.

Ryder, A. G., Alden, L. E., \& Paulhus, D. L. (2000). Is acculturation unidimensional or bidimensional? A head to head comparison in the prediction of personality, self-identity, and adjustment. Journal of Personality and Social Psychology, 79(1), 77-88. http://dx.doi.org/10.1037/0022-3514.79.1.49 
Savickas, M., \& Porfeli, E. (2012). Career Adapt-Abilities Scale: Construction, reliability, and measurement equivalence across 13 countries. Journal of Vocational Behavior, 80(3), 661-673. http://dx.doi.org/10.1016/j.jvb.2012.01.011

Shao, G. (2009). Understanding the appeal of user-generated media: A uses and gratification perspective. Internet Research, 19(1), 7-25. http://dx.doi.org/10.1108/10662240910927795

Solomon, G., Bamossy, G., Askegaard, S., \& Hogg, M. K. (2006). Consumer Behaviour: A European Perspective (3rd ed.). Harlow, England: Financial Times/Prentice Hall.

Unger, J., Gallaher, P., Shakib, S., Ritt-Olson, A., Palmer, P., \& Johnson, A., (2002). The AHIMSA Acculturation Scale: A New Measure of Acculturation for Adolescents in a Multicultural Society. Journal of Early Adolescence, 22(3), 225-251. http://dx.doi.org/10.1177/02731602022003001

Vijver, F., \& Phalet, K. (2004). Assessment in multicultural groups: The role of acculturation. Applied Psychology: An International Review, 53(2), 215-236. http://dx.doi.org/10.1111/j.1464-0597.2004.00169.x

Walker, D. (1999). The media's role in immigrant adaptation: How first-year Haitians in Miami use the media. Journalism \& Communication Monographs, 1(3), 157-196. http://dx.doi.org/10.1177/1522637999000100301

Winkelman, M. (1994). Cultural Shock and Adaptation. Journal of Counseling \& Development, 73(2), 121-126. http://dx.doi.org/10.1002/j.1556-6676.1994.tb01723.x

\section{Copyrights}

Copyright for this article is retained by the author(s), with first publication rights granted to the journal.

This is an open-access article distributed under the terms and conditions of the Creative Commons Attribution license (http://creativecommons.org/licenses/by/3.0/). 